\title{
The use of octreotide in the treatment of chylothorax
}

\section{Şilotoraksın tedavisinde oktreotidin kullanımı}

\author{
Hıdır Esme \\ Department of Thoracic Surgery, Health Sciences University, Konya Training and Research Hospital, Konya, Turkey
}

\begin{abstract}
Chylothorax is defined as abnormal accumulation of lymphatic fluid in the pleural space. Chylothorax is a rare case and generally occurs after thoracic and cardiac procedures. Chylothorax causes respiratory and nutritional problems and a significant mortality rate. Good knowledge of the underlying pathophysiology enables early diagnosis and prevention of the chronic complications related to immunodeficiency and malnutrition. Octreotide is a long-acting somatostatin analog that can reduce lymphatic fluid production and has been used as a new strategy in the treatment of chylothorax. In gastrointestinal tract, somatostatin and octreotide act on somatostatin receptors to reduce intestinal blood flow by vasoconstriction of the splanchnic vessels; decrease gastrointestinal motility; and inhibit gastric, pancreatic, and biliary secretions, thus reducing intestinal fat absorption and lymphatic flow in the thoracic duct. Octreotide is generally considered to be safe, with only occasional side effects. The side effects of octreotide are mainly related to its vasoconstrictive and antisecretory actions. The general consensus is for conservative management with octreotide to be instituted for 1 week before consideration of surgery. In case of either high flow rate chylothorax, especially after oesophageal surgery, or failure of conservative treatment with octreotide, operation is indicated.
\end{abstract}

Keywords: Chylothorax; octreotide; treatment.

Crav hylothorax is the accumulation of chyle within the chest cavity. Frequently seen causes of chylothorax are iatrogenic, including postsurgical cases following lung resections with mediastinal lymph node dissection, resections of the esophagus, and other thoracic operations; traumatic causes; malignant diseases; and hepatic cirrhosis. More uncommon causes, such as lymphangioleiomyomatosis and other disorders of the lymphatic system, Gorham's disease, sarcoidosis, amyloidosis, and thoracic irradiation, also may lead to chylothorax. About $6 \%$ of cases are idiopathic. ${ }^{[1]}$

\begin{abstract}
Özet
Şilotoraks plevral aralıkta lenfatik sıvının anormal birikimi olarak tanımlanır. Şilotoraks nadir bir durumdur ve genellikle torasik veya kardiyak işlemler sonrası ortaya çıkar. Şilotoraks solunumsal ve nütrisyonel problemlere ve anlamlı mortaliteye neden olur. Alttaki patofizyolojinin iyi bilinmesi erken tanıyı sağlar ve immün yetmezlik ve malnütrisyona bağlı kronik komplikasyonları önler. Octreotid lenfatik sıvı üretimini azaltan uzun etkili bir somatostatin analoğudur. Şilotoraks tedavisinde yeni bir yöntem olarak kullanılmaktadır. Gastrointestinal sistemde somatostatin ve octreotid, somatostatin reseptörleri üzerinden active olarak splenik damarların vazokonstrüksiyonu ile intestinal kan akımını azaltır. Ayrıca gastrointestinal motiliteyi, gastrik, pankreatik ve bilier sekresyonları azaltarak intestinal yağ emilimini azaltır ve sonuçta duktus torasikusta lenfatik akım azalır. Octreotid genel olarak güvenli kullanıma ve nadiren yan etkiye sahiptir. Octreotidin yan etkileri temel olarak vazokonstriktif ve sekresyonları inhibe edici etkisine bağlıdır. Genel konsensus cerrahiden önce bir hafta octreotid ile konservatif yaklaşımdır. Özellikle özefagus cerrahisi sonrası, şilotoraksın yüksek akımına sahip olduğu veya octreotid ile konservatif tedavinin yetersiz olduğu vakalarda operasyon endikedir.

Anahtar Sözcükler: Şilotoraks; oktreotide; tedavi.
\end{abstract}

Trauma-related chylothorax is by far the most common and can be caused by external blunt trauma or vertebral fracture as well as injury occurring during surgery or diagnostic procedures (lumbar arteriography, subclavian vein catheterization). Surgical injury can involve all levels: abdominal wounds after sympathectomy or node dissection, thoracic wounds after lung, esophageal, mediastinal or aortic surgery, cervical wounds after node dissection or extensive neck dissection. ${ }^{[2]}$ Esophageal surgery is probably the most common iatrogenic cause of chylothorax with incidence reported from 0.2 to $10.5 \%$ of operations. ${ }^{[3]}$ 


\section{Physiology of the Thoracic Duct}

The thoracic duct, which histologically is similar to blood vessels, drains lymph and chyle originating in the gastrointestinal tract, lymph from the liver, the abdominal wall and the lower limbs as well as the upper left limb and the left portion of the head and neck. ${ }^{[2]}$ The main function of the thoracic duct is to transport alimentary fats into the systemic circulation. Thus approximately 60 to $70 \%$ of oral fat intake passes through the thoracic duct. Chyle is consequently rich in chylomicrons, triglycerides, cholesterol and fat-soluble vitamins. Short chain fatty acids, however, are directly absorbed via the portal venous system and do not flow through the thoracic duct. Chyle also contains a high concentration of albümin (12-14 $\mathrm{g} / \mathrm{l})$. Other important elements include lymphocytes, which account for $95 \%$ of the cell content of chyle, immunoglobulins and digestive enzymes arising from the combination of lymphatic fluid and substances absorbed from the gut. ${ }^{[3]}$ This richness explains why chyle is a sterile bacteriostatic fluid and also why infected chylothorax is so rare.

\section{Diagnosis}

The diagnosis of chylothorax is made through clinical findings, radiology and the analysis of pleural fluid. Chylothorax is almost always an incidental finding post insertion of an intercostal catheter which is subsequently found to drain milky pleural fluid. ${ }^{[4]} \mathrm{A}$ chest $\mathrm{X}$-ray with a lateral and anteroposterior view confirms the presence of a pleural effusion and gives a starting point for monitoring. Computed tomography does not provide supplementary information and thus is not indicated. Magnetic resonance cholangiopancreatography may be useful to localize the cisterna chyli before percutaneous embolization. Bipedal lymphography is the gold standard imaging technique for the diagnosis of injury to the thoracic duct and for localization of the wound to prepare for embolization. ${ }^{[2]}$

Chylothorax is present in $99 \%$ of patients when triglyceride content is $>110 \mathrm{mg} / \mathrm{dL}$ and a cholesterol content $<200 \mathrm{mg} /$ $\mathrm{dL}$, whereas a triglyceride concentration $<50 \mathrm{mg} / \mathrm{dL}$ almost rules out chylothorax. Pseudochylothorax, which is also milky, is characterized by a cholesterol concentration of $>200 \mathrm{mg} /$ $\mathrm{dL}$ and lower triglyceride content $(<110 \mathrm{mg} / \mathrm{dL}$ ) (cholesterol: triglyceride ratio $>1)$. $^{[5]}$ Lipoprotein electrophoresis of the pleural fluid showing chylomicrons is confirmatory in uncertain cases.

\section{Complications}

Complications of a chylothorax include a mass effect which can negatively impact cardiorespiratory function as well as predispose the patient to nutritional, metabolic and immunological derangements. ${ }^{[6]}$ At an early stage, chylothorax can lead to severe cardiorespiratory and volemic complications. Respiratory distress can arise due to the development of pleural effusion, provoking progressive pulmonary atelectasia. ${ }^{[7]}$ Short-term electrolyte depletion leads to hypovolemia, metabolic acidosis, hyponatremia, hypocalcemia, and deficiencies in fat-soluble vitamins. ${ }^{[8]}$ In case of chroni- cization, malnutrition and immunologic complications can occur, responsible for a mortality rate of up to $50 \%$. Longterm loss of fatty acids and proteins can lead to a state of severe malnutrition. Immunodepression can arise due to the fall in cellular and humoral immunity, which is itself secondary to lymphocyte and immunoglobulin depletion. [9] Patients can thus become more vulnerable to infections, particularly in the postoperative period..$^{[10]}$

\section{Conservative Treatment}

Conservative management principles include pleural cavity drainage, reduction of chyle flow through dietary limitations (e.g. fasting, no/low-fat diets), nutritional support and the prevention of metabolic and chronic complications ${ }^{[6]} A$ diet rich in medium-chain fatty acids can lead to increased triglyceride and chylomicron concentrations, and water intake alone increases the drainage by $20 \%$ in certain patients. This may explain the poor resolution of chylothorax treated exclusively with medium-chain fatty acids. ${ }^{[3]}$ Total parenteral nutrition resolves chylothorax in $77 \%$ of cases, but creates medium- and longterm problems related to increased infections, thrombosis, or cholestasis. ${ }^{[1]]}$ Conservative management is currently complemented with various drugs that decrease the chyle leakage (etilefrine, somatostatin and analogs such as octreotide). ${ }^{[12-14]}$

\section{Etilefrin}

The use of etilefrine in chylothorax was reported for the first time by Guillem et al. ${ }^{[14]}$ Etilefrine has both $a$-adrenergic and $\beta$-adrenergic effects and is commonly used to treat conditions such as orthostatic hypotension and priapism. Guillem et al. explained that through its sympathomimetic effect, etilefrine induces contraction of the smooth muscles of the thoracic duct or main lymphatic duct, leading to a narrowed lumen, thereby decreasing chyle output. ${ }^{[14]} \mathrm{As}$ a result, the amount of chyle will be reduced and the site of injury will be repaired. Furthermore, etilefrine is relatively safe because it rarely causes side effects such as headache, tachycardia, hypertension, and anxiety when used in proper dose.

Ohkura et al. ${ }^{[15]}$ reported that the findings of their study suggest the effectiveness of etilefrine in patients with chylothorax following esophagectomy. Etilefrin (120 mg/day) was effective even in post-thoracic duct resection chylothorax, an often intractable condition that is difficult to treat conservatively. Ojima et al. ${ }^{[16]}$ reported the effectiveness of etilefrine therapy in patients with postoperative chylothorax. Ohkura et al. ${ }^{[17]}$ investigated the usefulness of etilefrine, a sclerosing agent, alone and combined therapies consisting of etilefrine and octreotide to broaden the medical treatment options for postesophagectomy chylothorax. They reported that the combined therapy consisting of etilefrine and octreotide may be optimal for the initial treatment of chylothorax after esophagectomy.

\section{Octreotide}

Although fat-free diet, total parenteral nutrition, pleural draniage by tube thoracostomy procedure, talk pleurodesis or 
surgical repair are the choices in treatment, conservative treatments with somatostatin and its anologs drugs are being more preferred novadays. ${ }^{[18]}$ Octreotide has similar activity to somatostatin, but selectivity is superior and half-life longer; octreotide also inhibits several pituitary and gastrointestinal hormones. The inhibition of serotonin and other intestinal peptides produces an increase in water absorption and intestinal transit and a decrease in pancreatic-duodenal secretion. More importantly, the resistance to splenic blood flow increases, and intestinal arteriolar flow decreases, in turn reducing lymphatic flow. ${ }^{[1]}$

There is no consensus on the route, dosage, and duration of octreotide administration for chylothorax. It could be administered as a continuous intravenous infusion or given twice daily as an intravenous bolus or subcutaneously. The effective Daily doses were from $7.2 \mu \mathrm{g} / \mathrm{kg}$ to $240 \mu \mathrm{g} / \mathrm{kg}$ (median, $68 \mu \mathrm{g} /$ $\mathrm{kg}$ ) for intravenous infusion and from $2 \mu \mathrm{g} / \mathrm{kg}$ to $68 \mu \mathrm{g} / \mathrm{kg}$ (median, $40 \mu \mathrm{g} / \mathrm{kg}$ ) for subcutaneous administration. The duration of administration ranged from 3 days to 43 days. Octreotide is generally considered to be safe, with only occasional side effects. The side effects of octreotide are mainly related to its vasoconstrictive and antisecretory actions. The reported adverse reactions include cramps, flatulence, nausea, diarrhea, necrotizing enterocolitis, hyperglycemia, transient hypothyroidism, and liver dysfunction. ${ }^{[19,20]}$

In 1990, Ulibarri et al. ${ }^{[21]}$ were the first to describe the successful use of somatostatin in an adult patient with chyle leak due to injury to thoracic duct following laryngectomy and lymphadenectomy. The benefits of octreotide in chylothorax following thoracic surgery were described in five separate reports. ${ }^{[1,22,23]}$ Bryant et al. ${ }^{[24]}$ conducted a retrospective study with the largest number of patients to date $(n=41)$, with chylothorax following pulmonary resections and lymphadenectomy by means of thoracotomy and robotic approach. Success rate of treatment with octreotide was $90 \%$. Gomez-Caro et al. ${ }^{[1]}$ described 4 patients with chylothorax following thoracic surgery. The author demonstrated remarkable drain reduction of $85-91 \%$ upon administration of octreotide when total parenteral nutrition (TPN) and nil by mouth (NBM) alone failed to change the drain output. Demos et al. ${ }^{[22]}$ commented on his experience of using octreotide in 5 patients with an $80 \%$ success rate.

Chylothorax in oesophagectomy is more common than in cardiothoracic surgery due to the anatomy and the nature of the surgery. Fujita et al. ${ }^{[25]}$ conducted a retrospective study in a single centre, comparing the use of octreotide along with total parenteral nutrition (TPN) and nil by mouth against TPN and nil by mouth only for patients with chylothorax following oesphagectomy and lymphadenectomy. The group receiving octreotide has significantly more successful conservative management compared with the group receiving TPN and bowel rest only. Disruption in the main thoracic duct itself in oesophagectomies tends to produce a high-output chylothorax as opposed to pulmonary resections. Fujita et al. ${ }^{[25]}$ found that a high-output chylotho$\operatorname{rax}(>1 \mathrm{l} /$ day), persisting for 2 days after $48 \mathrm{~h}$ treatment with octreotide is the predicting factor for failure of treatment with octreotide. This is supported by the findings of Okumura et al. ${ }^{[23]}$ whereby octreotide does reduce the drainage of 2-3 I/day chylothorax, but did not cause resolution of chylothorax.

Barbetakis et al. ${ }^{[26]}$ described a case of chylothorax following coronary artery bypass grafting, successfully managed with octreotide along with TPN and nil by mouth. The drain output showed significant reduction by $>80 \%$ and removal of drain at Day 8. Gabbieri et al. ${ }^{[27]}$ and Kilic et al. ${ }^{[28]}$ reported similar successful experience in moderate volume chylothorax following coronary artery bypass grafting. Authors recommended octreotide as an adjunct early in the conservative management following cardiac surgery.

\section{Surgery}

The timing of surgical management is debatable, however, generally conservative management is advised for at least two weeks before considering alternative interventional procedures $^{[4]}$ such as open mass ligation through an open thoracotomy ${ }^{[29]}$ or newer techniques such as ligation via thoracoscopy and thoracic duct embolisation. ${ }^{[6]}$ The likelihood of successful conservative management if drastically reduced when the daily chyle output exceeds $1000 \mathrm{ml} /$ day for $>5$ days $^{[9]}$ or $1500 \mathrm{ml} /$ day in an adult or $>100 \mathrm{ml} / \mathrm{kg}$ body weight per day in a child. ${ }^{[30]}$

If technically available, percutaneous embolization of the cisterna chyli or the thoracic duct by interventional radiography after $\mathrm{MRI}$ guidance is an attractive minimal invasive alternative to surgical treatment. For thoracic duct wounds after thoracic surgery, two surgical strategies predominate: direct wound ligature or en masse supradiaphragmatic ligature. Prior to operative management, lymphangiography or pre-operative enteral administration of a fat source to which methylene blue can be added can help to identify the leak source. ${ }^{[6]}$ For non-traumatic causes, other methods have been developed which are indicated in very rare cases: pleuroperitoneal shunt, pleurectomy, pleurodesis, or even radiotherapy. ${ }^{[31]}$

\section{Conclusion}

There is an increasing amount of evidence in the literature concerning the usefulness of octreotide for conservative treatment of chylothorax. Octreotide has been shown to be an effective, noninvasive treatment. It reduces the morbidity and mortality, hospital stay, and cost generated by complications of more aggressive treatment although no information regarding adverse side effects has been reported. The general consensus is for conservative management with octreotide to be instituted for 1 week before consideration of surgery. In case of either high flow rate chylothorax, especially after oesophageal surgery, or failure of conservative treatment with octreotide, operation is indicated. 
Conflict of interest: There are no relevant conflicts of interest to disclose.

\section{References}

1. Doerr $\mathrm{CH}$, Allen MS, Nichols FC, Ryu JH. Etiology of chylothorax in 203 patients. Mayo Clin Proc 2005;80:867-870.

2. Chalret du Rieu M, Baulieux J, Rode A, Mabrut JY. Management of postoperative chylothorax. J Visc Surg 2011;148(5):346-52.

3. Wemyss-Holden SA, Launois B, Maddern GJ. Management of thoracic duct injuries after oesophagectomy. Br J Surg 2001;88(11):1442-8.

4. Idris K, Sebastian M, Hefny AF, Khan FN, Abu-Zidan FM. Blunt traumatic tension chylothorax: case report and mini-review of the literature, World J Clin Cases 2016;4(11):380-384.

5. Waikar HD, Kamalaneson P, Mohamad Zamri MS, Jayakrishnan AG. Chylothorax after off-pump coronary artery bypass graft surgery: Management strategy. Ann Card Anaesth 2018;21(3):300-303.

6. Pillay TG, Singh B. A review of traumatic chylothorax. Injury 2016;47:545-550.

7. McGrath EE, Blades Z, Anderson PB. Chylothorax: aetiology, diagnosis and therapeutic options. Respir Med 2009;104(1):1-8.

8. Servelle M, Nogues C, Soulie J, Andrieux JB, Terhedebrugge R. Spontaneous, post-operative and traumatic chylothorax. J Cardiovasc Surg (Torino) 1980;21(4):475-86.

9. Wasmuth-Pietzuch A, Hansmann M, Bartmann P, Heep A. Congenital chylothorax: lymphopenia and high risk of neonatal infections. Acta Paediatr 2004;93(2):220-4.

10. Dumont AE, Mayer DJ, Mulholland JH. The suppression of immunologic activity by diversion of thoracic duct lymph. Ann Surg 1964;160:373-83.

11. Gómez-Caro Andrés $A$, Marrón Fernández $C$, Moradiellos Díez FJ, Díaz-Hellín Gude V, Pérez Antón JA, Martín de Nicolás JL. Octreotide for conservative management of postoperative chylothorax]. Arch Bronconeumol. 2004;40(10):473-5.

12. Rimensberger PC, Muller-Schenker B, Kalangos A, Beghetti $M$. Treatment of a persistent postoperative chylothorax with somatostatin. Ann Thorac Surg 1998;66:253-2.

13. Pratap U, Slavik Z, Ofoe VD, Onuzo O, Franklin RC. Octreotide to treat postoperative chylothorax after cardiac operations in children. Ann Thorac Surg 2001;72:1740-2.

14. Guillem P, Billeret V, Houcke ML, Triboulet JP. Successful management of post-esophagectomy chylothorax/chyloperitoneum by etilefrine. Dis Esophagus 1999;12:155-6.

15. Ohkura $Y$, Ueno $M$, lizuka T, Udagawa H. Effectiveness of etilefrine regimen for chylothorax after esophagectomy with thoracic duct resection. Esophagus 2018;15(1):33-38.

16. Ojima T, Nakamori $M$, Nakamura $M$, et al. A case of chylothorax appeared after surgery for esophageal cancer cured by admin- istration of octreotide/etilefrine and injection of OK-432 into the pleural cavity. J Jpn Surg Assoc 2014;75:1547-50.

17. Ohkura Y, Ueno M, lizuka T, Haruta S, Tanaka T, Udagawa H. New Combined Medical Treatment With Etilefrine and Octreotide for Chylothorax After Esophagectomy: A Case Report and Review of the Literature. Medicine (Baltimore). 2015;94(49):2214.

18. Karapınar K, Ulular Ö, Şahinalp Ş, Ersoy Ö, Özışık K, Yücel E. Effectiviness of somatostatin in the treatment of chylothorax: Case report. Bidder Tıp Bilimleri Dergisi 2010;2(2):28-30.

19. Roehr CC, Jung A, Proquitte $H$, et al. Somatostatin or octreotide as treatment options for chylothorax in young children: a systematic review. Intensive Care Med 2006;32:650-7.

20. Helin RD, Angeles ST, Bhat R. Octreotide therapy for chylothorax in infants and children: a brief review. Pediatr Crit Care Med 2006;7:576-9.

21. Ulibarri Jl, Sanz Y, Fuentes C, Mancha A, Aramendia M, Sanchez S. Reduction of lymphorrhagia from ruptured thoracic duct by somatostatin. Lancet 1990;336:258.

22. Demos NJ, Kozel J, Scerbo JE. Somatostatin in the treatment of chylothorax. Chest 2001;119:964-6.

23. Okumura H, Uchikado Y, Owaki T, Matsumoto M, Setoyama T, Kita $Y$ et al. Post-esophagectomy chylothorax successfully treated with combination of thoracic duct clipping and octreotide administration. Esophagus 2012;9:29-32.

24. Bryant AS, Minnich DJ, Wei B, Cerfolio RJ. The incidence and management of postoperative chylothorax after pulmonary resection and thoracic mediastinal lymph node dissection. Ann Thorac Surg 2014;98:232-7.

25. Fujita T, Daiko H. Efficacy and predictor of octreotide treatment for postoperative chylothorax after thoracic esophagectomy. World J Surg 2014;38:2039-45.

26. Barbetakis N, Xenikakis T, Efstathiou A, Fessatidis I. Successful octreotide treatment of chylothorax following coronary artery bypass grafting procedure. A case report and review of the literature. Hellenic J Cardiol 2006;47:118-22.

27. Gabbieri D, Bavutti L, Zaca F, Turinetto B, Ghidoni I. Conservative treatment of post-operative chylothorax with octreotide. Ital Heart J 2004;5:479-82.

28. Kilic D, Sahin E, Gulcan O, Bolat B, Turkoz R, Hatipoglu A. Octreotide for treating chylothorax after cardiac surgery. Tex Heart Inst J 2005;32:437-9.

29. Chamberlain MRC. Late presentation of tension chylothorax following blunt chest trauma. Eur J Cardiothorac Surg 2000;18:357359.

30. Marts BC, Naunheim KS, Fiore AC, Pennington DG. Conservative versus surgical management of chylothorax, Am J Surg 1992; 164:532-534.

31. Nair SK, Petko M, Hayward MP. Aetiology and management of chylothorax in adults. Eur J Cardiothorac Surg 2007;32(2):362-9. 